\title{
PENGARUH MOTIVASI INTRINSIK DAN EKSTRINSIK TERHADAP KINERJA PENGEMUDI GRABBIKE
}

\author{
Hamdani $^{1}$, Rita Yuni Mulyanti' ${ }^{2}$, Fatimah Abdillah $^{3}$ \\ ${ }^{1}$ STIE Pandu Madania, hamdaniajah17@gmail.com \\ ${ }^{2}$ STIE Pandu Madania, ritayuni77@yahoo.co.id \\ ${ }^{2}$ STIE Pandu Madania, fatimah.abdillah@ stiepm.ac.id
}

\begin{abstract}
ABSTRAK
Penelitian ini bertujuan untuk menganalisis bukti empiris pengaruh motivasi intrinsik dan ekstrinsik terhadap kinerja pengemudi grabbike yang beroperasi di kota dan kabupaten Bogor. Populasi dalam penelitian ini adalah seluruh pengemudi Grabbike Kota dan Kabupaten Bogor. Pengambilan sampel dilakukan dengan teknik non probability samplin. Data dikumpulkan dengan menggunakan kuesioner dan dianalisis dengan regresi linier berganda. Hasil penelitian menunjukkan bahwa motivasi intrinsik berpengaruh positif dan signifikan terhadap kinerja pengemudi grabbike di kota Bogor. Motivasi Ekstrinsik berpengaruh berpengaruh terhadap kinerja positif dan signifikan terhadap kinerja pengemudi grabbike di kota Bogor. Hasil penelitian juga menunjukkan bahwa semakin baik motivasi intrinsik dan ekstrinsik kinerja pengemudi akan semakin meningkat.
\end{abstract}

Kata kunci: motivasi intrinsik, motivasi ekstrinsik, kinerja, grabbike, pengemudi

\section{ABSTRACT}

This study aims to analyze the empirical evidence of the influence of intrinsic and extrinsic motivation on the performance of grabbike drivers operating in Bogor cities and districts. The population in this study were all Grabbike City and Bogor Regency drivers. Sampling is done by non probability sampling technique. Data were collected using a questionnaire and analyzed by multiple linear regression. The results showed that intrinsic motivation had a positive and significant effect on the performance of grabbike drivers in the city of Bogor. Extrinsic motivation influences the positive and significant performance of grabbike driver performance in the city of Bogor. The results also showed that the better intrinsic and extrinsic motivation of driver performance would increase.

Keywords: intrinsic motivation, extrinsic motivation, performance, grabbike, driver

Naskah diterima : \#date, Naskah dipublikasikan : \#date

\section{PENDAHULUAN}

Kesuksesan perusahaan yang bergerak di bidang jasa sangat ditentukan oleh sumber daya manusia (SDM), karena dalam proses pelayanan terjadi kontak antara sumber daya manusia (SDM) dan konsumen secara langsung. Perusahaan harus mengantisipasi segala kemungkinan terjadinya masalah dalam pengelolaan SDM, mulai dari seleksi hingga proses manajemen SDM yang lebih kompleks, maka peran sumber daya manusia (SDM) pada prosesnya bisa dilihat dari kinerja sumber daya manusianya. Menurut pendapat Prawisentono dalam usman (2010) kinerja merupakan suatu hasil kerja yang dicapai seseorang atau sekelompok orang dalam suatu organisasi sesuai dengan wewenang dan tanggung jawab masing-masing dalam rangka mencapai tujuan organisasi bersangkutan secara legal, tidak melanggar hukum dan sesuai norma ataupun etika.

Kinerja merupakan suatu hasil kerja yang dicapai seseorang dalam melaksanakan tugas-tugas yang dibebankan kepadanya yang didasarkan atas kecakapan, pengalaman, serta kesungguhan. Usaha yang dilakukan seseorang dalam pekerjaan didasari oleh motivasi yang ada 
didalam dirinya adalah untuk memenuhi segala sesuatu yang dibutuhkan atau diinginkannya. Robbins (2008) mengatakan bahwa agar para karyawan bisa termotivasi maka mereka hendaknya memiliki suatu pekerjaan dengan isi yang selalu merangsang untuk berprestasi. Martoyo (2000) mengungkapkan bahwa faktor yang berpengaruh dari kinerja antara lain motivasi, kepuasaan kerja, lingkungan kerja, sistem kompensasi, kepemimpinan dan prilaku lainnya. Beberapa faktor yang mempengaruhi kinerja karyawan sebagai sumber daya terpenting perusahaan adalah motivasi.

Hasibuan (2006) menjelaskan bahwa motivasi adalah hal yang menyebabkan mendorong perilaku manusia supaya mau bekerja giat dan antusias mencapai hasil yang optimal. Motivasi yang dimaksud terdiri dari 2 macam, yaitu: motivasi yang datang dalam diri karyawan yang sering disebut motivasi intrinsik dan Faktor motivasi ekstrinsik yaitu dorongan yang berasal dari luar. Motivasi ekstrinsik adalah motivasi yang bersumber dari luar diri yang turut menentukan prilaku seseorang dalam kehidupan (Luthans,2011). Motivasi ekstrinsik muncul dari luar diri seseorang kemudian selanjutnya mendorong orang tersebut untuk membangun dan menumbuhkan semangat motivasi pada diri orang tersebut untuk merubah seluruh sikap yang dimiliki olehnya saat ini ke arah yang lebih baik. Ketika pekerja telah termotivasi di dalam dirinya dan mendapatkan dorongan dari kerabat ataupun perusahaan maka akan mendapatkan kinerja yang luar biasa, yang dapat menguntungkan bagi dirinya ataupun perusahaannya.

Perkembangan bisnis di era digital, telah mendorong tumbuhnya bisnis online. Salah satu dari bisnis yang berbasis online adalah ojeg online. Tren ojeg online mengalami peningkatan beberapa tahun belakangan ini seiring meningkatnya kebutuhan akan transportasi yang cepat di area Jabodetabek. Kemudahan dan kecepatan waktu pesan ojeg melalui aplikasi serta kecepatan waktu tempuh menjadi faktor kunci banyaknya peminat ojeg online. Selain itu kepastian dan murahnya tarif menjadi daya tarik yang mampu memikat masyarakat untuk beralih ke moda transportasi ini.

Tabel 1. Perusahaan transportasi yang menggunakan aplikasi sistem booking online

\begin{tabular}{cll}
\hline No & Nama perusahaan & \multicolumn{1}{c}{ Deskripsi } \\
\hline 1 & PT.Gojek Indonesia & Tahun berdiri 2010 \\
2 & Grabbike & Berdiri pada Mei 2015, berpusat di Malaysia \\
3 & Grabtaxi & Masuk ke indonesia sejak Juni 2014 \\
4 & Uber & Berdiri sejak 2009,berpusat di amerika serikat \\
5 & Bajaj app & Angkutan bajaj yang lahir baru dijakarta \\
6 & Transek & Berdiri sejak September 2012 \\
7 & Wheel line & Transportasi yang menetapkan harga sesuai wilayah \\
8 & Bangjek & Jasa ojeg yang didirikan oleh andri harsil \\
9 & Ojeg syar'i & Ojeg Surabaya yang berbasis syar'i \\
10 & Blue jek & Berdiri sejak 17 september 2015 \\
11 & Bo jek & Ojeg online yang berada hanya disekitaran bogor \\
\hline
\end{tabular}

Sumber: http:/economy.okezone.com/(diakses tanggal 04 Oktober 2017) 
Table 1 di atas menjelaskan mengenai perusahaan transportasi booking online yang saat ini sedang berkembang di Kota dan Kabupaten Bogor menurut penelitian sebelumnya Syafrino (2017) adalah perusahaan Grabbike, Gojek, Uber, jumlah dari pengemudi Grabbike pada tahun 2017 adalah 4994, gojek adalah 1105, dan Uber adalah sebanyak 4000. Pengemudi dengan jumlah paling banyak adalah pengemudi Grabbike, karena penerimaan pengemudi baru yang pihak Grab lakukan ini tak lepas dari banyaknya orang yang tertarik bergabung pada pihak grab. Grabbike merupakan jasa transportasi booking melalui aplikasi yang sedang berkembang (id.technasia.com) meski saat awal gojeg lebih banyak armadanya. Grabbike merupakan salah satu perusahaan jasa transportasi yang memiliki 220.000 mitra pengemudi yang tersebar di wilayah Asia Tenggara (managing director untuk Grab Indonesia) (cnnindonesia), ini tak lepas dari sistem Grabbike yang menganggap bahwa pengemudi adalah mitra.

Sebagai perusahaan jasa pengantaran yang menggunakan sistem digital grabbike sangat bergantung pada kinerja para pengemudi, untuk mempertahankan kualitas pelayanan kepada penumpang maka Grabbike melakukan berbagai upaya, yang menjadikan perusahaan membebankan kepada pengemudi untuk memberikan pelayanan yang baik. Beberapa kriteria pengemudi yang direkrut oleh Grabbike diantaranya adalah: memiliki kemampuan untuk menggunakan aplikasi Grabbike, memiliki kemampuan yang sesuai dengan persyaratan pengemudi, dapat menyelesaikan tugas dan mematuhi peraturan dari perusahaan, mampu memberikan pelayanan yang baik pada pelanggan, dapat bekerjasama dan menjalin hubungan baik dengan rekan-rekan kerja, kreatif dalam menggunakan fitur baru dari Grabbike.

Manajemen pernah mengalami masalah berkaitan dengan keluhan pengemudi tentang dua tuntutan pengemudi yaitu ketika penetapan tarif dan hukuman untuk pelanggar kebijakan perusahaan (cnnindonesia, 2017). Tetapi ketika pendapatan dan insentif ditingkatkan meski hari libur dan dalam hari raya idul fitri 2017 dibanding hari-hari biasa. Ridzki Kramadibarata (managing director, Grab Indonesia) mengatakan kenaikan frekuensi dan pengguna layanan Grab itu terjadi di semua daerah. perhatian masyrakat terhadap pengguna moda transportasi Grab semakin meningkat bukan dari sisi jumlah, melainkan juga frekuensi perjalanan.

\section{KAJIAN LITERATUR \\ Teori Motivasi}

Teori motivasi yang menitikberatkan pada kebutuhan agar memotivasi orang-orang. Kebutuhan-kebutuhan ini menimbulkan dorongan internal yang memotivasi prilaku tertentu sebagai usaha memenuhi kebutuhan tersebut. Kebutuhan seorang individu bagaikan katalog halhal tersembunyi yang diinginkan dan diusahakan agar terpenuhi.

\section{Motivasi Intrinsik}

Motivasi intrinsik adalah motivasi yang timbul dalam diri karyawan itu sendiri. Menurut teori Robbins (2008) motivasi intrinsik timbul ketika motivasi ekstrinsik sudah terpenuhi. Sedangkan motivasi menurut Nawawi(2000) adalah motivasi yang mendorong seseorang untuk berprestasi yang bersumber dalam individu, berupa kesadaran mengenai pentingnya manfaat atau makna pekerjaan yang dilaksanakan. Motivasi intrinsik secara operasional diukur menggunakkan lima dimensi dan indikator menurut Herzberg (dalam Robbins,2008) yaitu Keberhasilan, Pekerjaan itu sendiri, Penghargaan, Tanggung jawab dan Pengembangan diri.

\section{Motivasi Ekstrinsik}

Motivasi ekstrinsik adalah motivasi yang timbul dari luar diri yang turut menentukan prilaku seseorang dalam kehidupan seseorang yang dikenal dengan teori hygiene factor (Luthans, 2011). Menurut Herzberg dalam Robbins dan Judge (2008), dimensi dan indikator motivasi ekstrinsik,yaitu:

a. Job status (status kerja),indikatornya: jabatan kerja yang sesuai waktu kerja, gaji, dan beratnya pekerjaan 
b. Interpersonal realition (hubungan antar pribadi), indikatornya: komunikasi yang terjalin baik dengan atasan dan teman kerja.

c. Company policy administration, indikatornya: kebijakan dari perusahaan, pengawasan

d. Supervisor (supervisi), indikatornya: pengarahan atasan kepada bawahan, job desain

e. Job security, indikatornya: melindungi karyawan saat bekerja.

f. Working condition (kondisi kerja), indikatornya: lingkungan kerja yang nyaman, fasilitas perusahaan yang memadai.

g. Wages and salary (gaji dan upah), indikatornya: gaji yang didapat sesuai dengan pekerjaan yang dilakukan.

\section{Kinerja}

Kinerja merupakan suatu tindakan seseorang yang merupakan kombinasi dari kemampuan usaha yang dilakukannya agar mendapatkan hasil yang diinginkannya, dengan adanya dorongan yang lebih atau kemampuan yang cukup maka seseorang bisa menyelesaikan pekerjaannya sesuai dengan yang diharapkannya.

Berdasarkan Yusuf Hamid,dkk (2012), berpendapat ada lima dimensi yang mempengaruhi kinerja karyawan, yaitu:

a. Job skill, kemampuan dan keahlian karyawan yang mendukung pelaksanaan tugas, yang mencakup kemampuan, pengetahuan, keterampilan, interpersonal dan kecakapan teknis.

b. Discipline, adalah kemampuan karyawan untuk mematuhi peraturan dan kebijakan untuk berprilaku dengan organisasi, termasuk penyelesaian tugas, kehadiran, istirahat kerja dan penyelesaian kerja.

c. Responsibility, kemampuan seseorang untuk melakukan atau menyelesaikan pekerjaan dengan benar, contohnya waktu yang digunakan untuk bekerja dan kualitas pekerjaan.

d. Cooperation, kemampuan untuk membangun interaksi dengan rekan rekan dan membantu satu sama lain dalam melaksanakan tugas.

e. Creativity, mengacu pada kemampuan karyawan untuk berperilaku mencoba hal-hal baru.

\section{Kerangka Konseptual}

Dasar pemikiran yang melandasi penelitian ini adalah untuk menghubungkan pengaruh motivasi intrinsik dan motivasi ekstrinsik dengan kinerja Grabbike. Dengan asumsi motivasi intrinsik dan motivasi ekstrinsik berpengaruh positif dan signifikan terhadap kinerja pengemudi Grabbike, berdasarkan hal tersebut terdapat tiga hal konsep utama yaitu: motivasi intrinsik, motivasi ekstrinsik dan kinerja pengemudi Grabbike.

\section{Keterkaitan Motivasi Intrinsik Terhadap Kinerja}

Motivasi intrinsik adalah motivasi yang mendorong seseorang untuk berprestasi yang bersumber dalam individu, berupa kesadaran mengenai pentingnya manfaat atau makna pekerjaan yang dilaksanakan. Ketika seseorang untuk berprestasi maka mereka bekerja dengan penuh semangat karena sadar akan manfaat dari kerjanya, Sehingga bisa diketahui bahwa motivasi dapat membuat seseorang meningkatkan kinerjanya. Pendapat tersebut didukung oleh hasil penelitian yang dilakukan oleh Linawati (2014) yang diketahui bahwa motivasi kerja intrinsik (X1) dan motivasi kerja Ekstrinsik (X2) berpengaruh positif dan signifikan terhadap $\operatorname{kinerja}(\mathrm{Y})$

Berdasarkan uraian diatas, maka keterkaitan antara motivasi intrinsik terhadap kinerja pengemudi digambarkan sebagai berikut:

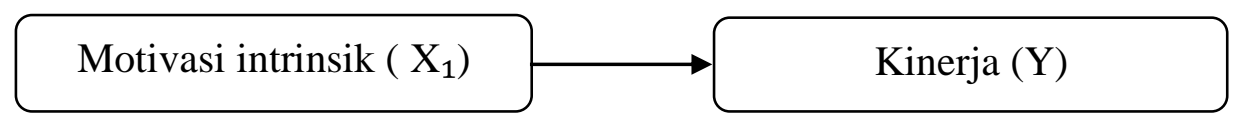

Gambar 1. Pengaruh motivasi intrinsik terhadap kinerja 


\section{Keterkaitan Motivasi Ekstrinsik Terhadap Kinerja}

Motivasi ekstrinsik muncul dari luar diri seseorang, kemudian selanjutnya mendorong orang tersebut untuk membangun dan menumbuhkan semangat motivasi pada diri orang tersebut untuk merubah seluruh sikap yang dimiliki olehnya saat ini kearah yang lebih baik, Sehingga ketika sikap berubah kearah yang lebih baik maka kinerja pun akan semakin meningkat. Pendapat tersebut didukung oleh hasil penelitian yang telah dilakukan Fatuho Faruwu (2017), yang diketahui bahwa motivasi intrinsik dan Motivasi ekstrinsik secara bersama-sama atau simultan dan parsial sangat berpengaruh terhadap kinerja karyawan di RS Rajawali dan STIKES Rajawali Bandung.

Berdasarkan uraian di atas, maka keterkaitan motivasi ekstrinsik terhadap kinerja pengemudi digambarkan sebagai berikut:

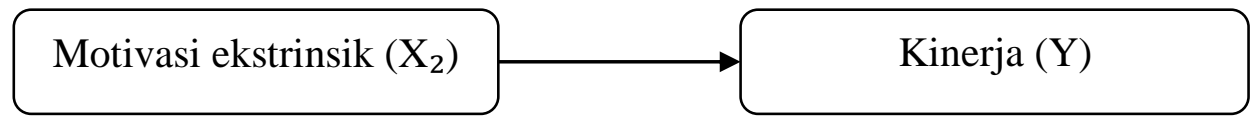

Gambar 2. Pengaruh motivasi ekstrinsik $\left(\mathrm{X}_{2}\right)$ terhadap kinerja $(\mathrm{Y})$

\section{Keterkaitan Motivasi Intrinsik dan Ekstrinsik Terhadap Kinerja}

Motivasi intrinsik yang mendorong seseorang untuk berprestasi yang bersumber dalam individu, berupa kesadaran mengenai pentingnya manfaat atau makna dari pekerjaan itu sendiri. Ketika seseorang sadar akan pentingnya manfaat dari pekerjaan maka akan meningkatkan kinerjanya. Motivasi ekstrinsik adalah dorongan yang muncul dari luar diri seseorang, kemudian selanjutnya mendorong orang tersebut untuk membangun dan menumbuhk an semangat motivasi pada diri orang tersebut untuk merubah seluruh sikap yang dimilikinya ke arah yang lebih baik, sehingga akan meningkatkan kinerjanya.

Pendapat tersebut didukung oleh hasil penelitian yang dilakukan oleh Heri Puspito Lukito,et al. yang menyatakan bahwa terdapat pengaruh secara simultan dan parsial yang signifikan dari motivasi intrinsik, motivasi ekstrinsik, dan pengalaman kerja terhadap kinerja karyawan (studi kasus pada BTPN Syariah Semarang).

Berdasarkan uraian di atas, maka keterkaitan antara motivasi intrinsik dan motivasi ekstrinsik terhadap kinerja pengemudi digambarkan sebagai berikut:

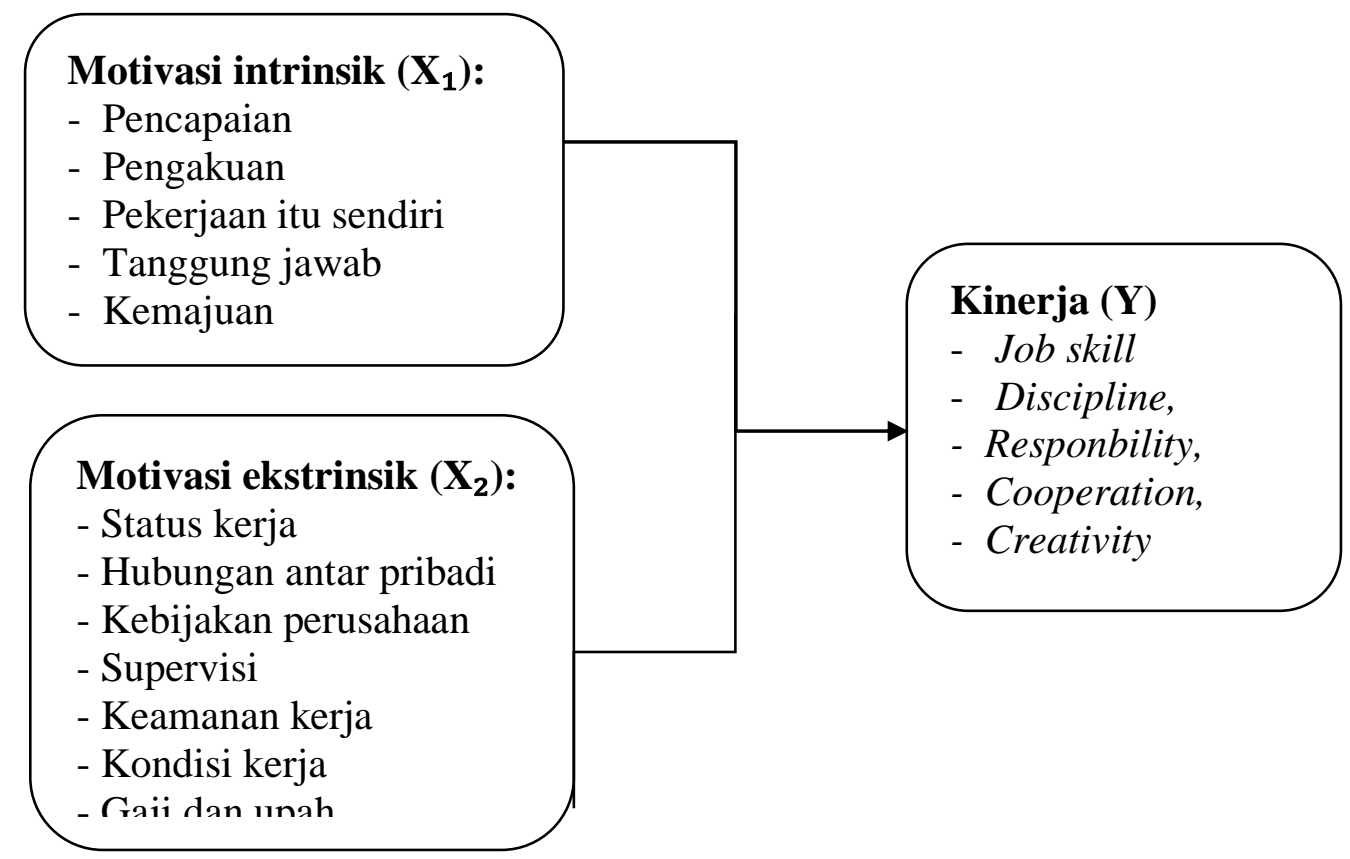

Gambar 3. Keterkaitan motivasi intrinsik dan ekstrinsik terhadap kinerja 


\section{Hipotesis Penelitian}

Berdasarkan kajian penelitian sebelumnya dan kerangka konseptual yang dikemukakan di atas, maka dapat diperoleh hipotesis sebagai berikut:

$\mathrm{H} 1=$ Motivasi intrinsik berpengaruh positif dan signifikan terhadap kinerja pengemudi Grabbike yang beroperasi di Kota dan Kabupaten Bogor.

$\mathrm{H} 2=$ Motivasi ekstrinsik berpengaruh positif dan signifikan terhadap kinerja pengemudi Grabbike yang beroperasi di Kota dan Kabupaten Bogor.

$\mathrm{H} 3=$ Motivasi intrinsik dan motivasi ekstrinsik berpengaruh positif dan signifikan terhadap kinerja pengemudi Grabbike yang beroperasi di kota dan Kabupaten Bogor.

\section{METODE PENELITIAN}

Menurut Sugiono (2010) untuk penentuan jumlah sampel dari populasi tertentu bisa dengan taraf kesalahan 1\%, 5\% dan 10\%. Pada penulisan ini menggunakan eror 10\% sehingga besarnya sampel dapat dihitung sebagai berikut:

$$
\begin{aligned}
& \mathrm{n}=4994 / 1+4994(0.1)^{2} \\
& \mathrm{n}=4994 / 50,94=98,03
\end{aligned}
$$

Populasi dalam penelitian ini adalah seluruh pengemudi Grabbike Kota dan Kabupaten Bogor. Pada perhitungan berdasarkan rumus diatas maka di peroleh hasil 98.03, akan tetapi dalam penelitian ini di bulatkan menjadi 100 responden.

Untuk mengumpulkan data setiap variabel dalam penelitian ini, terlebih dahulu ditentukan indikator-indikator untuk mengukur variabel yang dituangkan dalam tabel operasionalisasi variabel di bawah ini.

\begin{tabular}{|c|c|c|c|}
\hline No & Variabel & Konsep & Indikator \\
\hline 1 & $\begin{array}{l}\text { Motivasi } \\
\text { Intrinsik(dalam } \\
\text { diri) }\end{array}$ & $\begin{array}{l}\text { Motivasi Intrinsik adalah yang } \\
\text { mendorong seseorang untuk } \\
\text { berprestasi yang bersumber } \\
\text { dalam individu, berupa kesadaran } \\
\text { mengenai pentingnya manfaat } \\
\text { atau makna pekerjaan yang } \\
\text { dilaksanakan, Nawawi (2000) }\end{array}$ & $\begin{array}{l}\text { 1. Pencapaian } \\
\text { 2. Pengakuan } \\
\text { 3.Pekerjaan itu sendiri } \\
\text { 4.Tanggung jawab } \\
\text { 5. Kemajuan }\end{array}$ \\
\hline 2 & $\begin{array}{l}\text { Motivasi } \\
\text { ekstrinsik (dari } \\
\text { luar) }\end{array}$ & $\begin{array}{l}\text { Motivasi yang timbul dari luar } \\
\text { diri yang turut menentukan } \\
\text { prilaku seseorang dalam } \\
\text { kehidupan seseorang yang } \\
\text { dikenal dengan teori hygiene } \\
\text { faktor, Luthans (2011) }\end{array}$ & $\begin{array}{l}\text { 1. Status kerja } \\
\text { 2. Hubungan antar pribadi } \\
\text { 3. Kebijakan perusahaan } \\
\text { 4. Supervisi } \\
\text { 5. Keamanan kerja } \\
\text { 6. Kondisi kerja } \\
\text { 7. Gaji dan upah }\end{array}$ \\
\hline 3 & Kinerja & $\begin{array}{l}\text { Kinerja adalah suatu hasil kerja } \\
\text { yang dicapai seseorang dalam } \\
\text { melaksanakan tugas-tugas yang } \\
\text { dibebankan kepadanya yang } \\
\text { didasarkan berdasarkan } \\
\text { kecakapan pengalaman, Hasibuan } \\
(2001) \text {. }\end{array}$ & $\begin{array}{l}\text { 1. Job skill } \\
\text { 2. Discipline } \\
\text { 3. Responsibility } \\
\text { 4. Cooperation } \\
\text { 5. Creativity }\end{array}$ \\
\hline
\end{tabular}

Tabel 2. Operasional Variabel Penelitian

Pengumpulan data dilakukan dengan penyebaran kuesioner yang disusun berdasarkan indikator pada setiap variabel. Kuesioner diisi oleh pengemudi grabbike yang terpilih. Selanjutnya data yang diperoleh dianalisis secara deskriptif dan dilakukan verifikasi 
terhadap hipotesis yang telah disusun. Pengujian hipotesis dilakukan dengan analisis regresi linier berganda dengan persamaan:

Dimana:

$$
\mathbf{Y}=\mathbf{a}+\mathbf{b}_{1} \mathbf{X}_{1}+\mathbf{b}_{2} \mathbf{X}_{2}+\mathbf{e}
$$

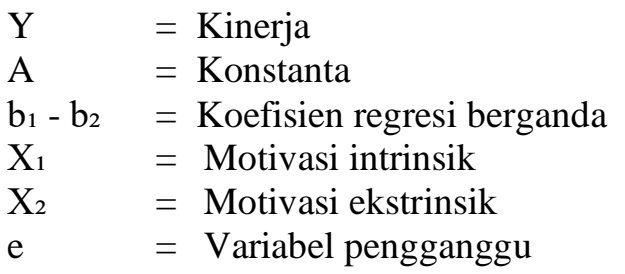

Dari model persamaan yang telah dibentuk, akan digunakan untuk memprediksi pengaruh antara beberapa variabel besar terhadap variabel terikat dengan melihat besarnya koefisien masing-masing variabel bebas.

\section{ANALISIS DATA DAN PEMBAHASAN \\ Analisis Deskriptif}

Analisis Deskriptif digunakan untuk mendeskripsikan atau menggambarkan kondisi variabel yaitu Motivasi Intrinsik, Motivasi Ekstrinsik dan Kinerja. Menyajikan data yang telah dikumpulkan didalam penelitian serta memperlajari bagaimana melakukan pengukuran nilainilai statistik. Berikut hasil (output) kueisoner yang dibagikan kepada 100 responden.

\section{Tanggapan Responden Mengenai Motivasi Intrinsik (X1)}

Motivasi Intrinsik memiliki lima Indikator, yaitu: pencapaian dan keberhasilan, pengakuan berupa jaminan keamanan kerja,kesempatan belajar dari peluang, merencanakan tugas sendiri,kesempatan untuk maju dan berkembang. Kelima Indikator dapat di representasikan dalam 5 pernyataan dapat dilihat pada tabel berikut:

Tabel 3. Tanggapan Responden terhadap Variabel Motivasi Intrinsik

\begin{tabular}{|c|c|c|c|c|c|c|c|}
\hline No & Pernyataan & SS & $\mathbf{S}$ & $\mathbf{N}$ & TS & STS & Skor \\
\hline 1 & $\begin{array}{l}\text { Saya terdorong untuk mencapai } \\
\text { target pengantaran dengan baik. }\end{array}$ & 31 & 55 & 12 & 2 & - & $\begin{array}{c}415 / 500= \\
83 \%\end{array}$ \\
\hline \multirow{3}{*}{2} & $\%$ & $31 \%$ & $55 \%$ & $12 \%$ & $2 \%$ & - & \multirow{3}{*}{$\begin{array}{c}409 / 500= \\
81.8 \%\end{array}$} \\
\hline & $\begin{array}{c}\text { Lingkungan yang aman menjadi } \\
\text { dorongan untuk saya bekerja lebih } \\
\text { baik }\end{array}$ & 24 & 61 & 15 & - & - & \\
\hline & $\%$ & $24 \%$ & $61 \%$ & $15 \%$ & - & - & \\
\hline 3 & $\begin{array}{l}\text { Saya terdorong untuk memberikan } \\
\text { pelayanan yang baik kepada } \\
\text { konsumen, karena perusahaan selalu } \\
\text { menilai baik pekerjaan saya apabila } \\
\text { sesuai dengan prosedur perusahaan }\end{array}$ & 27 & 60 & 12 & 1 & - & $\begin{array}{c}413 / 500= \\
82.6 \%\end{array}$ \\
\hline \multirow{3}{*}{4} & $\%$ & $27 \%$ & $60 \%$ & $12 \%$ & $1 \%$ & - & \multirow{3}{*}{$\begin{array}{c}415 / 500= \\
83 \%\end{array}$} \\
\hline & $\begin{array}{l}\text { Saya terdorong untuk melakukan } \\
\text { tugas dengan baik karena tugas } \\
\text { merupakan suatu tanggung jawab. }\end{array}$ & 29 & 57 & 14 & - & - & \\
\hline & $\%$ & $29 \%$ & $57 \%$ & $14 \%$ & - & - & \\
\hline 5 & $\begin{array}{l}\text { Saya terdorong untuk merencanakan } \\
\text { tugas sendiri tanpa adanya } \\
\text { pengawasan dari siapapun }\end{array}$ & 24 & 65 & 10 & 1 & - & $\begin{array}{l}412 / 500= \\
82.4 \%\end{array}$ \\
\hline
\end{tabular}


$\begin{array}{lllll}\% & 24 \% & 65 \% & 10 \% & 1 \%\end{array}$

Sumber: Data primer diolah Agustus 2018

Berdasarkan tabel 3, diperoleh informasi bahwa tanggapan responden dengan skor tertinggi $83 \%$ mengenai pernyataan ke empat yaitu tentang mengerjakan tugas sesuai tanggung jawab dan target pekerjaan, yaitu: Saya terdorong untuk melakukan tugas dengan baik karena tugas merupakan suatu tanggung jawab, dengan jawaban dari responden menjawab sangat setuju sebanyak $29 \%$ dan setuju sebanyak $57 \%$, sedangkan tanggapan terendah dengan skor 81,8\% adalah dari pernyataan nomor 2 mengenai Lingkungan yang aman menjadi dorongan untuk saya bekerja lebih baik, dimana lingkungan pada pengemudi Grabbike berada di jalan dan didasarkan pada situasi lingkungan yang kurang aman bila dibandingkan dengan pekerjaan dikantor. Jawaban responden terhadap variabel Motivasi Intrinsik di peroleh skor sebesar $82.56 \%$ menunjukan bahwa Motivasi Intrinsik pada pengemudi Grabbike sangat baik.

\section{Tanggapan Responden Mengenai Motivasi Ekstrinsik (X2)}

Analisis Deskriptif jawaban Responden mengenai Motivasi Ekstrinsik didasarkan pada jawaban responden atas pernyataan seperti yang terdapat pada kueisoner yang disebarkan kepada 100 responden. Terdapat tujuh Indikator dalam pernyataan mengenai Motivasi ekstrinsik, yaitu: jabatan kerja atau status kerja, komunikasi yang terjalin baik dengan teman kerja, kebijakan dari perusahaan, pengarahan atasan kepada bawahan, melindungi karyawan saat bekerja, lingkungan kerja, upah atau gaji yang di dapat. . Variasi jawaban responden untuk variabel Motivasi Ekstrinsik dapat dilihat pada Tabel 4 berikut ini:

Tabel 4. Tanggapan Responden terhadap Variabel Motivasi Ekstrinsik

\begin{tabular}{|c|c|c|c|c|c|c|c|}
\hline No & Pernyataan & SS & $\mathbf{S}$ & $\mathbf{N}$ & TS & STS & Skor \\
\hline 1 & $\begin{array}{c}\text { Keamanan dan kenyamanan yang } \\
\text { diberikan perusahaan kepada saya } \\
\text { sebagai mitra membuat saya } \\
\text { termotivasi dalam bekerja }\end{array}$ & 31 & 56 & 12 & 1 & - & $\begin{array}{l}417 / 500= \\
83.4 \%\end{array}$ \\
\hline \multirow[b]{2}{*}{2} & $\%$ & $31 \%$ & $56 \%$ & $12 \%$ & $1 \%$ & - & \\
\hline & $\begin{array}{l}\text { Komunikasi yang baik dengan } \\
\text { teman dan rekan kerja lain } \\
\text { membuat saya terdorong untuk } \\
\text { bekerja }\end{array}$ & 19 & 62 & 19 & - & - & $\begin{array}{l}400 / 500= \\
80 \%\end{array}$ \\
\hline \multirow[b]{2}{*}{3} & $\%$ & $19 \%$ & $62 \%$ & $19 \%$ & - & - & \\
\hline & $\begin{array}{l}\text { Kebijakan perusahaan yang sesuai } \\
\text { dan mudah diiterima, membuat } \\
\text { saya termotivasi dalam bekerja }\end{array}$ & 24 & 56 & 20 & - & - & $\begin{array}{c}404 / 500= \\
80.8 \%\end{array}$ \\
\hline \multirow{3}{*}{4} & $\begin{array}{c}\% \\
\text { Saya terdorong untuk bekeria }\end{array}$ & $24 \%$ & $56 \%$ & $20 \%$ & - & - & \\
\hline & $\begin{array}{c}\text { karena adanya pengarahan yang } \\
\text { diberikan Kordinator lapangan } \\
\text { yang mempermudah pekerjaan } \\
\text { saya }\end{array}$ & 30 & 51 & 18 & 1 & - & $\begin{array}{l}410 / 500= \\
82 \%\end{array}$ \\
\hline & $\%$ & $30 \%$ & $51 \%$ & $18 \%$ & $1 \%$ & - & \\
\hline \multirow[t]{2}{*}{5} & $\begin{array}{c}\text { Jaminan asuransi kecelakaan saat } \\
\text { bekerja menjadi dorongan untuk } \\
\text { saya untuk tetap melakukan } \\
\text { pekerjaan }\end{array}$ & 23 & 53 & 23 & 1 & - & $\begin{array}{l}398 / 500= \\
79.6 \%\end{array}$ \\
\hline & $\%$ & $23 \%$ & $53 \%$ & $23 \%$ & $1 \%$ & - & \\
\hline
\end{tabular}


Intensitas perhatian yang diberikan perusahaan melalui aplikasi dan sosial media menjadi dorongan untuk saya bekerja. $\%$

$7 \quad$ Saya terdorong untuk rajin bekerja karena pendapatan dan bonus yang saya terima sesuai dengan pekerjaan yang saya lakukan. $\%$

$\begin{array}{cccccc}29 & 55 & 13 & 2 & 1 & 409 / 500= \\ 29 \% & 55 \% & 13 \% & 2 \% & 1 \% & \\ & & & & & \\ 34 & 45 & 20 & - & 1 & \begin{array}{c}411 / 500= \\ 82.2 \%\end{array} \\ & & & & & \\ 34 \% & 45 \% & 20 \% & - & 1 \% & \end{array}$

Sumber: Data di olah pada Agustus 2018

Berdasarkan tabel di atas telah didapat informasi mengenai motivasi ekstrinsik dari 7 instrument pernyataan. Berdasarkan tabel 4 dapat diperoleh informasi bahwa tanggapan responden dengan nilai skor tertinggi $83.4 \%$ mengenai pada pernyataan pertama yaitu tentang keamanan dan kenyamanan yang diberikan perusahaan kepada saya sebagai mitra membuat saya termotivasi dalam bekerja. Sebanyak $31 \%$ menjawab sangat setuju, dan 56\% menjawab setuju meskipun ada 1 responden yang menjawab tidak setuju. Selanjutnya skor sebesar $82,2 \%$ ditemukan pada pernyataan bahwa responden termotivasi untuk rajin bekerja karena pendapatan dan bonus yang mereka terima sesuai dengan pekerjaan yang dilakukan. Nilai skor tertinggi ketiga (82\%) terdapat pada pernyataan perusahaan selalu memberi arahan dan informasi yang membuat pengemudi aman dalam mengerjakkan tugas. Sedangkan tanggapan terendah dari pernyataan nomor 5 mengenai Jaminan asuransi kecelakaan saat bekerja menjadi dorongan untuk saya untuk tetap melakukan pekerjaan dengan skor $79.6 \%$ dan ada pernyataan yang menjawab tidak setuju karena responden menganggap masih belum mengetahui pasti informasi untuk mendapatkan asuransi bila terjadi kecelakaan saat bekerja.

\section{Pernyataan Mengenai Kinerja (Y)}

Kinerja memiliki lima Indikator, yaitu: kemampuan dan pengetahuan kerja, penyelesaian tugas dan kehadiran, waktu kerja dan kualitas kerja, interaksi yang baik dengan rekan kerja, kreatifitas, karyawan. Kelima Indikator dapat di representasikan dalam 5 pernyataan dapat dilihat pada tabel berikut:

Tabel 5. Tanggapan Responden terhadap Kinerja

\begin{tabular}{|c|c|c|c|c|c|c|c|}
\hline No & Pernyataan & SS & $\mathbf{S}$ & $\mathbf{N}$ & TS & STS & Skor \\
\hline 1 & $\begin{array}{l}\text { Saya dapat melakukan proses } \\
\text { (cara) kerja dengan baik }\end{array}$ & 25 & 61 & 14 & - & - & $\begin{array}{c}411 / 500= \\
82.2 \%\end{array}$ \\
\hline \multirow[b]{2}{*}{2} & $\%$ & $25 \%$ & $61 \%$ & $14 \%$ & - & - & \\
\hline & $\begin{array}{l}\text { Saya dapat mencapai target } \\
\text { pekerjaan sesuai dengan yang } \\
\text { ditetapkan perusahaan }\end{array}$ & 22 & 62 & 16 & - & - & $\begin{array}{l}406 / 500= \\
81.2 \%\end{array}$ \\
\hline \multirow[b]{2}{*}{3} & $\%$ & $22 \%$ & $62 \%$ & $16 \%$ & - & - & \\
\hline & $\begin{array}{c}\text { Saya dapat bekerja dengn baik } \\
\text { tanpa adanya pengawasan dari } \\
\text { atasan/perusahaan }\end{array}$ & 27 & 55 & 18 & - & - & $\begin{array}{l}409 / 500= \\
81.8 \%\end{array}$ \\
\hline \multirow[b]{2}{*}{4} & $\%$ & $27 \%$ & $55 \%$ & $18 \%$ & - & - & \\
\hline & $\begin{array}{c}\text { Saya dan rekan lain saling } \\
\text { menghargai satu sama lain dalam } \\
\text { bekerja }\end{array}$ & 22 & 55 & 23 & - & - & $\begin{array}{l}399 / 500= \\
79.8 \%\end{array}$ \\
\hline
\end{tabular}




\begin{tabular}{ccccccc}
$\%$ & $22 \%$ & $55 \%$ & $23 \%$ & - & - & \\
$5 \quad \begin{array}{c}\text { Saya bisa memanfaatkan fitur } \\
\text { terbaru dari perusahaan dengan } \\
\text { kreatifitas saya. }\end{array}$ & 29 & 54 & 16 & 1 & - & $411 / 500=$ \\
$\%$ & $29 \%$ & $54 \%$ & $16 \%$ & $1 \%$ & - & $82.2 \%$ \\
\hline
\end{tabular}

Sumber: Data primer diolah pada Agustus 2018

Berdasarkan tabel 5 dapat diperoleh informasi bahwa tanggapan responden dengan Skor tertinggi $82.2 \%$ mengenai pada pernyataan pertama yaitu tentang Saya dapat melakukan proses (cara) kerja dengan baik dengan hasil 25\% menjawab sangat setuju, dan $61 \%$ menjawab setuju. Sedangkan tanggapan terendah dari pernyataan nomor empat, yaitu: Saya dan rekan lain saling menghargai satu sama lain dalam bekerja. Jawaban responden terhadap variabel Kinerja di peroleh Skor 79.8\% yang menunjukan bahwa kinerja pada pengemudi Grabbike sangat baik.

\section{Uji validitas}

Validitas adalah ukuran yang menunjukan sejauh mana instrumen pengukur mampu mengukur apa yang diukur.berikut adalah hasil dari pengujian validitas dengan jumlah sampel adalah sebanyak 30 sampel. Dan 30 responden dengan 17 instrumen pernyataan dapat dilihat pada tabel 6

Tabel 6. Hasil pengujian Validitas

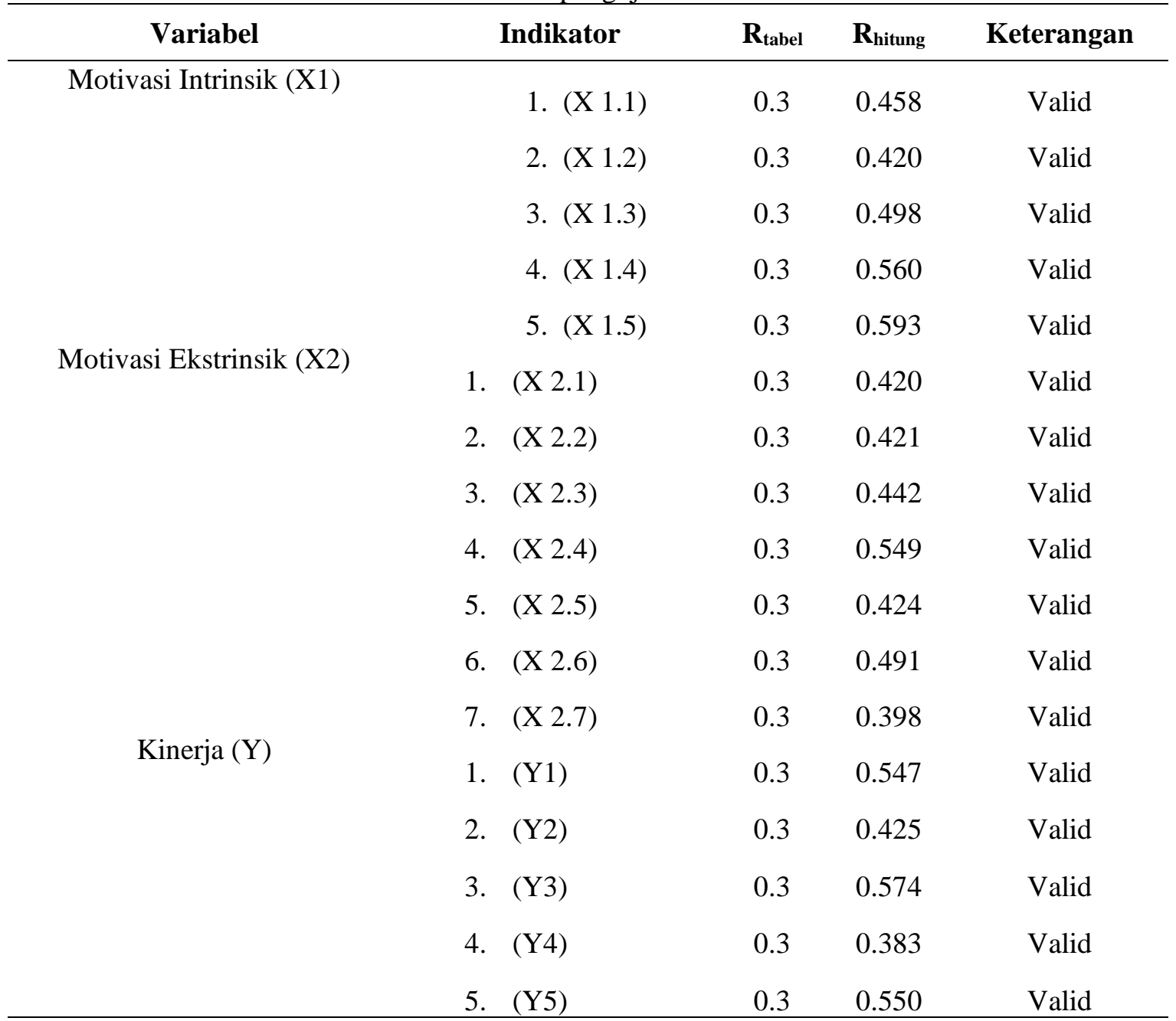

Sumber: data Primer diolah Agustus 2018 
Berdasarkan tabel di atas apabila nilai $\mathrm{R}_{\text {hitung }}>0.3$, maka item pernyataan itu dikatakan Valid dan sebaliknya, bila nilai $\mathrm{R}_{\text {hitung }}<0.3$, maka item pernyataan itu dikatakan Tidak valid/Invalid. Berdasarkan hasil pengolahan uji validitas terhadap 17 isntrumen pernyataan maka dapat dikatakan Valid karena Nilai $R_{\text {hitung }}>\mathbf{0 . 3}$, oleh karena itu 17 instrumen pernyataan tersebut dimasukkan atau dapat diolah dalam pengolahan data selanjutnya.

\section{Uji Reliabilitas}

Uji reliabilitas adalah suatu index yang menunjukan sejauh mana hasil suatu pengukuran dapat dipercaya. Suatu kueisoner dinyatakan reliable atau handal jika jawaban seseorang terhadap pertanyaan adalah konsisten atau stabil dari waktu ke waktu (Ghozali, 2001)

Tabel 7. Hasil Uji Reliabilitas

\begin{tabular}{cccc}
\hline Variabel & $\begin{array}{c}\text { Cronbach's } \\
\text { Alpha }\end{array}$ & N of Items & Keterangan \\
\hline Motivasi Intrinsik (X1) & 0.741 & 6 & Reliabel \\
Motivasi Ekstrinsik (X2) & 0.722 & 8 & Reliabel \\
Kinerja(Y) & 0.741 & 6 & Reliabel \\
\hline
\end{tabular}

Sumber: Data primer diolah Agustus 2018

Berdasarkan Tabel 7, hasil uji coba menunjukan Cronbach's Alpha pada variabel motivasi intrinsik, motivasi Ekstrinsik dan Kinerja lebih dari 0.6 artinya (a) $>0.6$ sehingga dengan demikian dapat dikatakan bahwa Instrument yang telah di uji cobakan ini Reliabel. Maka pernyataan tersebut dapat di masukan dan diolah dalam pengolahan selanjutnya.

\section{Uji Asumsi Klasik}

Uji asumsi klasik regresi linear berganda dapat dikelompokkan kedalam 3 kategori yaitu; uji Normalitas, uji multikolinearitas dan heteroskedastisitas, hasil dari pengolahan uji asumsi klasik regresi linear berganda dapat dilihat sebagai berikut:

Hasil uji asumsi klasik menunjukan bahwa uji normalitas terpenuhi, dengan menggunakan uji statistik non-parametrik Kolmogorov-Smirnov (K-S) yang mana kriteria suatu data residual berdistribusi normal yaitu nilai Asymp. Sig. (2-tailed) $>0,05$ dan hasil menunjukan bahwa data dalam penelitian ini berdistribusi normal karena nilai nya Kolmogorov-Smirnov $>0.05$ yaitu 0.818. kemudian untuk uji multikolinieritas hasil nya menunjukan bahwa antara variabel motivasi instriksik dan ekstrisik tidak berkorelasi atau multikolinieritas tidak terjadi dalam model penelitian karena diperoleh nilai VIF lebih kecil dari 10 yaitu 1.25 untuk variabel motivasi instriksik dan ekstrisik. Hasil uji heteroskedastisitas menunjukan bahwa tidak terjadi heteroskedastisitas karena terlihat pada titik-titik yang menyebar secara acak di atas dan di bawah angka nol (0) dan tidak membentuk suatu pola tertentu, maka dapat dikatakan bahwa regresi tidak mengalami ganguan heteroskedastisitas sehingga model regresi layak dipakai untuk memprediksi kinerja kerja berdasarkan masukan variabel bebas 


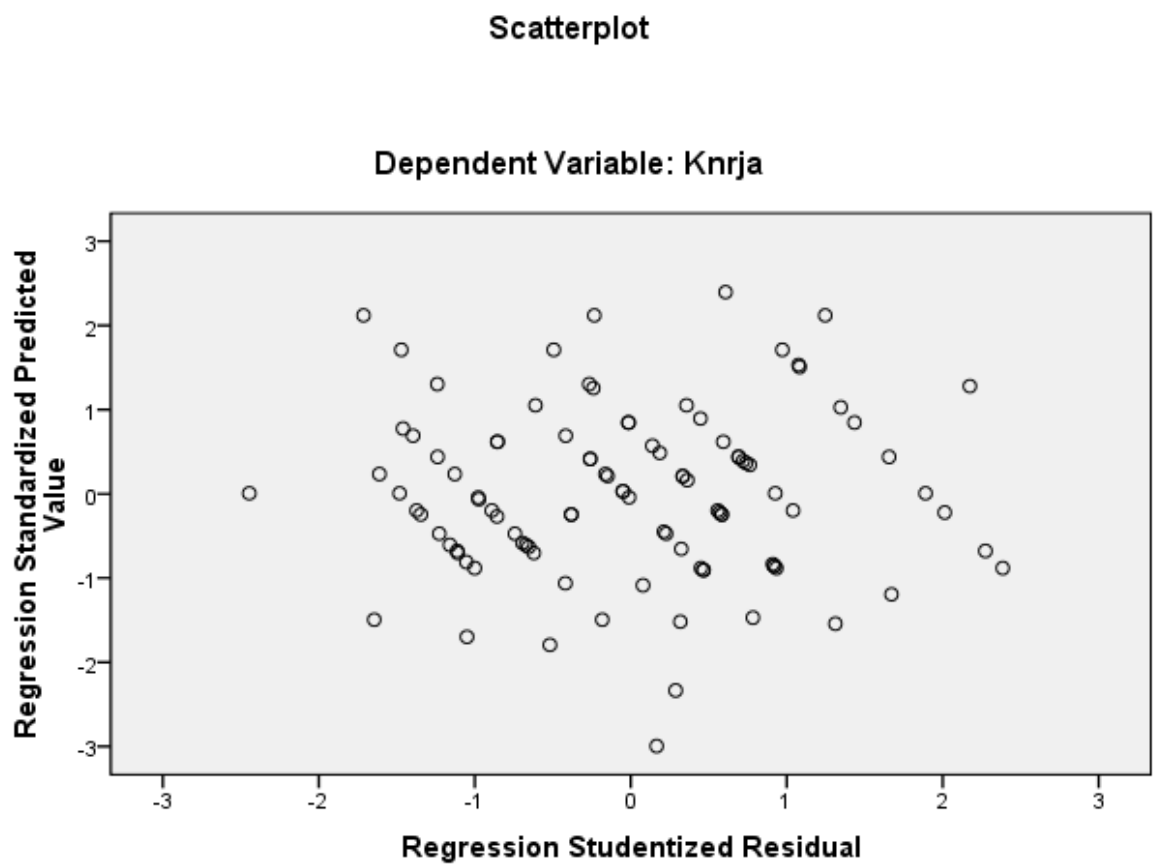

\section{Analisis Regresi Linear Berganda}

Hasil analisis menunjukan nilai Konstanta besarnya 3.845, variabel X1 besarnya 0.259 , variabel X2 besaranya 0.232 . berdasarkan tabel tersebut maka dapat ditulis dalam bentuk Unstandardized Coefficients maka diperoleh persamaan berikut ini:

$$
\mathrm{Y}=3845+0.259 \mathrm{X}_{1}+0.232 \mathrm{X}_{2}
$$

Dengan hasil signifikan koefisiensi (Uji t) menyatakan motivasi intrinsik berpengaruh terhadap kinerja pengemudi Grabbike Kota dan Kabupaten Bogor, lalu tingkat signifikansi $0.004<0.05$, motivasi Ekstrinsik (X2) berpengaruh terhadap kinerja pengemudi Grabbike Kota dan Kabupaten Bogor dengan tingkat Signifikansi $0.003<0.05$.

\section{Pengujian Simultan (F)}

Pengujian Hipotesis secara Simultan (Uji F) bertujuan untuk mengukur besarnya pengaruh variabel bebas secara bersama-sama terhadap variabel terikat. Hasil hipotesis dalam pengujian ini adalah:

Tabel 8. Hasil pengujian Simultan (Uji F)

\begin{tabular}{cccccc}
\hline Model & $\begin{array}{c}\text { Sum of } \\
\text { Squares }\end{array}$ & Df & $\begin{array}{c}\text { Mean } \\
\text { Square }\end{array}$ & F & Sig. \\
\hline 1. Regression & 127.372 & 2 & 63.686 & 14.599 & 0.000 \\
Residual & 423.138 & 97 & 4.362 & & \\
Total & 550.510 & 99 & & & \\
\hline
\end{tabular}

Sumber: Data primer diolah Agustus 2018

Dari tabel diatas, Nilai $F_{\text {hitung }} 14.599$, dan nilai statistik $F_{\text {tabel }}=(F$ 0,05(2) $(97)=3,09$

Hasil yang didapat dengan membandingkan Jika $F_{\text {hitung }}$ dan $\mathrm{F}_{\text {tabel }}$ :

$\begin{array}{llll}\mathrm{F}_{\text {hitung }}>\mathrm{F}_{\text {tabel }} & \mathrm{Sig} & \text { à } \\ 14,599> & >09 . & 0,000<0\end{array}$


Karena nilai $\mathrm{t}_{\text {hitung }} 14,599>\mathrm{t}_{\text {tabel }}$ 3,09 dan nilai probbabilitas variabel (X1) dengan tingkat Signifikansi $0.000<0.05$, maka dapat dinyatakan bahwa $\mathrm{H}_{\mathrm{o}}$ ditolak dan $\mathrm{H}_{\mathrm{a}}$ diterima, artinya bahwa motivasi intrinsik(X1) dan Motivasi Ekstrinsik (X2) berpengaruh terhadap kinerja pengemudi Grabbike Kota dan Kabupaten Bogor

\section{Uji Koefisien Determinasi}

Koefisien determinasi merupakan ukuran untuk mengetahui kesesuaian atau ketepatan antara nilai dugaan atau garis regresi dengan data sampel. Apabila nilai koefisien korelasi sudah diketahui, maka untuk mendapatkan koefisien determinasi dapat diperoleh. (Ghozali 2005) Koefisien determinasi yang digunakan adalah nilai Adjusted R Square karena lebih dapat dipercaya dalam mengevaluasi model regresi. Nilai Adjusted $\mathrm{R}$ square dapat naik atau turun apabila variabel independen ditambahkan ke dalam model.

Tabel 9. Koefisien Determinasi Model Summary

\begin{tabular}{ccccc}
\hline Model & R & R Square & $\begin{array}{c}\text { Adjusted R } \\
\text { Square }\end{array}$ & $\begin{array}{c}\text { std. Error of } \\
\text { the Estimate }\end{array}$ \\
\hline 1 & 481 (a) & 231 & 216 & 20.886 \\
\hline
\end{tabular}

Sumber: Data primer diolah Agustus 2018

Pada tabel 9 diatas Nilai R Square Sebesar 0.231 dan Adjusted R Square Sebesar 0.216. Hal ini 21,6\% dari kinerja dapat dijelaskan oleh variabel motivasi Intrinsik (X1) dan motivasi ekstrinsik (X2). Sedangkan sisanya $78.4 \%$ dipengaruhi variabel-variabel lainnya yang tidak diteliti.

\section{Pembahasan \\ Pengaruh Motivasi Intrinsik Terhadap Kinerja}

Hasil analisis regresi menunjukkan bahwa motivasi intrinsik(X1) berpengaruh terhadap kinerja dengan koefisien sebesar 259. Hal ini berarti menunjukkan bahwa motivasi intrinsik memiliki pengaruh yang positif dan signifikan terhadap kinerja pengemudi Grabbike Kota dan Kabupaten Bogor. Penelitian ini sesuai dengan hasil penelitian Heri Puspito Lukito, et al. (2016) menunjukan bahwa adanya pengaruh motivasi Intrinsik dan ekstrinsik terhadap kinerja baik secara parsial maupun simultan.

\section{Pengaruh Motivasi Ekstrinsik Terhadap Kinerja.}

Hasil analisis regresi menunjukkan bahwa motivasi ekstrinsik (X2) memiliki pengaruh yang positif dan signifikan terhadap kinerja pengemudi Grabbike Kota dan Kabupaten Bogor. Penelitian ini sesuai dengan hasil penelitian Heri Puspito Lukito, et al. (2016) menunjukan bahwa adanya pengaruh motivasi Intrinsik dan ekstrinsik terhadap kinerja baik secara parsial maupun simultan.

\section{Pengaruh Motivasi Intrinsik dan Motivasi Ekstrinsik Terhadap Kinerja.}

Variabel motivasi intrinsik(X1) dan Motivasi Ekstrinsik (X2) berpengaruh terhadap kinerja pengemudi Grabbike yang beroperasi di Kota dan Kabupaten Bogor, dengan nilai signifikansi $<0.05$, Penelitian ini sesuai dengan hasil penelitian Fatuho Waruwu. (2017) menunjukan bahwa adanya pengaruh motivasi Intrinsik dan ekstrinsik terhadap kinerja baik secara parsial maupun simultan

\section{PENUTUP}

Berdasarkan hasil dari penelitian variabel motivasi Intrinsik berpengaruh positif dan signifikan terhadap kinerja atau dapat dikatakan Motivasi intrinsik berpengaruh terhadap kinerja. Variabel motivasi Ekstrinsik berpengaruh positif dan signifikan $(0,003)$ terhadap kinerja atau dapat dikatakan Motivasi ekstrinsik berpengaruh terhadap kinerja. Berdasarkan Uji Simultan (Uji F) 
hasil membuktikan bahwa semua variabel yaitu motivasi intrinsik dan motivasi ekstrinsik secara Simultan atau bersama-sama berpengaruh positif dan signifikan (0.000) terhadap kinerja.

Peneliti menyarankan untuk peneliti selanjutnya melakukan penelitian tentang motivasi intrinsik dan ekstrinsik yang mengaitkan dengan variabel lain sehingga dapat memperkaya keilmuan pada bidang manajemen SDM (Sumber Daya Manusia) dan faktor faktor lain yang tidak diteliti dalam penelitian ini yang memiliki pengaruh cukup besar terhadap kinerja seperti dari faktor tugas dan tanggung jawab, pengaruh lingkungan dan juga keamanan dan kenyamanan dari perusahaan, pembenahan harus dikaitkan dengan visi dan strategi perusahaan Selanjutnya peneliti menyarankan sebagai bahan pertimbngan oleh perusahaan Grabbike dalam upaya peningkatan kinerja agar lebih baik dan produktif adalah sebagai berikut:

a. Perusahaan disarankan agar dapat meningkatkan motivasi intrinsik yang mendapatkan tanggapan baik dari pengemudi, sehingga dapat menjadi lebih baik dimasa depan.

b. Perusahaan agar memperhaatikan dan meningkatkan motivasi ekstrinsik yang berdasarkan tanggapan responden meningkatkan motivasi mereka untuk bekerja, sehingga perusahaan diharapkan dapat tetap menjaga motivasi intrinsik para pengemudinya melalui keamanan dan kenyamanan bekerja, kompensasi dan bonus yang memadai, informasi yang jelas dan juga meningkatkan layanan asuransi dari perusahaan.

c. Perusahaan agar dapat melihat faktor lain yang tidak dimasukan dalam penelitian ini yang berdasarkan dari hasill lain masih ada variabel lain yang dapat mempengaruhi kinerja dari responden.

\section{REFERENSI}

Ghazali, Imam. 2001. Aplikasi Analisis Multivariate dengan Program SPSS, Semarang: BP UNDIP.

Hasibuan, Malayu S.P. 2001. Manajemen Sumber Daya Manusia. Jakarta: PT. Bumi Aksara. 2007. Manajemen Sumber Daya Manusia. Jakarta: PT. Bumi Aksara. 2010. Manajemen Sumber Daya Manusia. Jakarta: PT. Bumi Aksara. 2012. Manajemen Sumber Daya Manusia. Jakarta: PT. Bumi Aksara.

Heri Puspito Lukito. 2016. Pengaruh Motivasi Intrinsik, Motivasi Ekstrinsik dan Pengalaman Kerja TerhadapKinerja ( studi kasus pada BTPN Syariah semarang). Jurnal. Universitas Pandanaran Semarang.

Linawati. 2014. Analisis Tentang Pengaruh Motivasi Kerja Intrinsik dan Motivasi Kerja Ekstrinsik Terhadap Kinerja Karyawan (studi kasus pada PT. Angkasa pura bandara udara internasional Ahmad Dani Semarang). Jurnal. Sekolah Tinggi Kerirgantaraan (STTKD) Semarang.

Luthans, Fred. 2011. "Prilaku Organisasi". Yogyakarta: penerbit: Andi.

Martoyo. S. 2000. Manajemen Sumber Daya Manusia. Yogyakarta: BPFE.

Nawawi, H Hadafi. 2000. Manajemen Sumber Daya Manusia. Cetakan ketiga. Yogyakarta: Gama press.

Prawisentono. 2008. Kebijakan Kinerja Karyawan. Yogyakarta BPFE.

Stepphan Robbins \& Timothy A.Judge. 2008. "Prilaku Organisasi 1". Jakarta: Salemba 4.

Syafrino Aprima. 2017. Efesiensi dan Dampak Ojeg Online Terhadap Kesempatan Kerja dan Kesejahteraan. Bogor. Jurnal. Institut Pertanian Bogor Jurusan Manajemen.

Warowo, Fatuho. 2017. Analisis tentang pengaruh motivasi intrinsik dan motivasi ekstrinsik terhadap kinerja karyawan(studi kasus dirumah sakit rajawali dan ST Widodo, SuseroTriyanto.1990. Indikator Ek Dasar Perhitungan Perencanaan Indonesia Yogya: Kanisius IKES Rajawali Bandung). Jurnal. STIKES Rajawali Bandung. 
Yusuf, R. M, Hamid et all. 2012. The Antecedents of Employee's Performance: case study of Nickel Minings Company, Indonesia. IOSR Journal Of Bussines and Management, 2,2228.

Website:

http://economy.okezone.com/ diakses pada 4 Oktober 2017

https://m.cnnindonesia.com. diakses 10 Oktober 2017

https://id.techinasia.com. diakses pada 15 Oktober 2017

https://www.grab.com diakses pada 20 Oktober 2017

https://jabar.pojoksatu.co.id diakses pada tanggal 25 Desember 2017

https://id.wikipedia.org diakses pada tanggal 27 Desember 2017 